Sahar Siddik-Sayyid MD FRCA, Marie Aouad-Maroun MD, Danielle Sleiman MD, Maria Sfeir MD, Anis Baraka MD FRCA

\title{
Epidural tramadol for postoperative pain after Cesarean section
}

Purpose: To compare the post-operative analgesic effect of $100 \mathrm{mg}$ vs $200 \mathrm{mg}$ epidural tramadol and saline in patients undergoing elective Cesarean section.

Methods: Sixty healthy women undergoing Cesarean delivery with epidural anesthesia were randomly allocated into three groups ( $n=20$ in each). Patients received, at skin closure via the epidural catheter, $100 \mathrm{mg}$ tramadol (Group I), $200 \mathrm{mg}$ tramadol (Group II) or $10 \mathrm{ml}$ saline (Control group). Pain scores and side effects were evaluated at I, 2, 4, 8, 12 and $24 \mathrm{hr}$ after surgery. Mean times to the first analgesic administration, as well as the cumulative doses of analgesic requirements over $24 \mathrm{hr}$ postoperatively were compared.

Results: The mean time to first analgesic administration was longer in patients who received $100 \mathrm{mg}$ tramadol $(4.5 \pm 3.1 \mathrm{hr})$ and the $200 \mathrm{mg}$ tramadol $(6.6 \pm 3.4 \mathrm{hr})$ than in those who received placebo $(2.8 \pm 2 \mathrm{hr})$. The mean cumulative doses of meperidine over $24 \mathrm{hr}$ were less in the $100 \mathrm{mg}$ tramadol group $\left(0.3 \pm 0.3 \mathrm{mg} \mathrm{kg}^{-1}\right)$ and the $200 \mathrm{mg}$ tramadol group $\left(0.3 \pm 0.3 \mathrm{mg} \cdot \mathrm{kg}^{-1}\right)$ than in the control group $\left(0.7 \pm 0.4 \mathrm{mg} \cdot \mathrm{kg}^{-1}\right)$. Also, the mean doses of diclofenac over $24 \mathrm{hr}$ were less in the $100 \mathrm{mg}$ tramadol group ( $156 \pm 59 \mathrm{mg}$ ) and the $200 \mathrm{mg}$ tramadol group (142 $\pm 62 \mathrm{mg}$ ) than in the control group (214 $\pm 70 \mathrm{mg}$ ). However, no difference was obtained between patients receiving $100 \mathrm{mg}$ and $200 \mathrm{mg}$ tramadol concerning all parameters studied.

Conclusion: Epidural tramadol $100 \mathrm{mg}$ can provide adequate postoperative analgesia without respiratory depression in patients after Cesarean delivery.

Objectif : Comparer l'effet analgésique postopératoire de $100 \mathrm{mg}$ vs $200 \mathrm{mg}$ de tramadol épidural ou d'une solution salée chez des patientes qui doivent subir une césarienne.

Méthode : Soixante femmes en santé admises pour une césarienne sous anesthésie épidurale ont été réparties au hasard en trois groupes ( $n=20$ chacun). Elles ont reçu, lors de la fermeture cutanée et au moyen d'un cathéter épidural, $100 \mathrm{mg}$ (groupe I) ou $200 \mathrm{mg}$ (groupe II) de tramadol ou $10 \mathrm{ml}$ de solution salée (groupe témoin). Les scores de douleur et les effets secondaires ont été évalués à $1,2,4,8$, 12 et $24 \mathrm{~h}$ après l'intervention. On a comparé les temps moyens de la première administration d'analgésique et quelles en étaient les doses cumulatives postopératoires demandées pendant $24 \mathrm{~h}$.

Résultats : Le temps moyen pour la première analgésie a été plus long chez les patientes qui ont reçu $100 \mathrm{mg}$ $(4,5 \pm 3,1 \mathrm{~h})$ ou $200 \mathrm{mg}(6,6 \pm 3,4 \mathrm{~h})$ de tramadol que chez celles qui n'ont reçu que le placebo $(2,8 \pm 2 \mathrm{~h})$. Pendant $24 \mathrm{~h}$ après la césarienne, les doses moyennes cumulatives de mépéridine ont été moindres dans les groupes I et II $\left(0,3 \pm 0,3 \mathrm{mg} \cdot \mathrm{kg}^{-1} ; 0,3 \pm 0,3 \mathrm{mg} \cdot \mathrm{kg}^{-1}\right)$ que dans le groupe témoin $\left(0,7 \pm 0,4 \mathrm{mg} \cdot \mathrm{kg}^{-1}\right)$ et les doses moyennes de diclofénac ont été plus faibles dans les groupes l et II (I56 $\pm 59 \mathrm{mg}$; $42 \pm 62 \mathrm{mg}$ ) que dans le groupe témoin $(214 \pm 70 \mathrm{mg}$ ). Cependant, aucune différence ria été notée entre les patientes des groupes 1 et II, et ce, pour tous les paramètres étudiés.

Conclusion : L'administration épidurale de $100 \mathrm{mg}$ de tramadol peut fournir une analgésie postopératoire adéquate sans dépression respiratoire chez des patientes qui ont subi une césarienne.

From the Department of Anesthesiology, American University of Beirut, Beirut - Lebanon.

Address correspondence to: Anis Baraka MD FRCA, Department of Anesthesiology, American University of Beirut, Beirut - Lebanon. Fax: 961-1-744-464; E-mail: abaraka@aub.edu.lb

Accepted for publication May 2, 1999 
$\mathrm{T}$ HE use of intrathecal or epidural opioids has been recommended for relief of postoperative pain including postoperative pain after Cesarean section..$^{1-5}$ Tramadol, a relatively new, centrally-acting analgesic drug has a low but preferential activity at opioid receptors, and also inhibits both noradrenaline and 5-hydroxytryptamine (5-HT) neuronal reuptake, and facilitates 5-HT release. ${ }^{6-10}$ Thus, it has been advocated as an analgesic, without respiratory depression. ${ }^{6-10}$

Tramadol depresses spinal nociceptive receptors in the rat. ${ }^{11}$ Also, previous studies have shown that epidural tramadol can produce effective postoperative analgesia in patients undergoing major abdominal surgery without any serious side effects. ${ }^{12-13}$ Using an initial epidural tramadol dose of $50 \mathrm{mg}$ was less effective than $100 \mathrm{mg}$ tramadol. ${ }^{13}$

The present report investigates the effect of 100 $\mathrm{mg}$ epidural tramadol vs $200 \mathrm{mg}$ for postoperative analgesia in patients undergoing elective Cesarean section. The results were compared with those achieved in a control group receiving epidural saline.

\section{Methods}

After institutional approval and informed consent, we studied 60 full term pregnant patients, ASA physical status I or II, undergoing elective Cesarean section. Exclusion criteria include obesity (weight $>115 \mathrm{~kg}$ ), short stature < than $152 \mathrm{~cm}$, diabetes, pregnancyinduced hypertension, chronic hypertension, heart disease and multiple gestation. At the preoperative visit, patients were instructed in the evaluation of pain using the visual analog scores (VAS) of $0-10 \mathrm{~cm}(0 \mathrm{~cm}$ = no pain, and $10 \mathrm{~cm}=$ the worst pain possible) .

Patients were premedicated with atropine $0.5 \mathrm{im}$ one hour before surgery. Intravenous access was established on arrival in the anesthetic room, and I litre lactated Ringer's solution was infused. Epidural anesthesia was performed with the patient in the sitting position, at the $\mathrm{L}_{2-3}$ or $\mathrm{L}_{3-4}$ interspace. The epidural space was identified by the loss of resistance technique, using a 17-Gauge Tuohy needle and the epidural catheter was inserted 3$4 \mathrm{~cm}$ into the epidural space. The patient was then positioned supine, with $15^{\circ}$ left uterine displacement. All patients received $5 \mathrm{~L} \cdot \mathrm{min}^{-1}$ oxygen, by face mask, until delivery. A test dose of $3 \mathrm{ml}$ plain lidocaine $2 \%$ to be followed by $17 \mathrm{ml}$ was injected epidurally. Additional boluses of the local anesthetic were given as clinically indicated. The upper level of epidural blockade required was $\mathrm{T}_{4-6}$. Hypotension defined as a reduction of the systolic blood pressure $>20 \%$, was treated with $i v$ boluses of ephedrine $5 \mathrm{mg}$ and additional rapid infusion of Lactated Ringer's solution. Ephedrine treatment was repeated every two minutes if hypotension persists or recurs.

At skin closure, patients were randomized to receive in the epidural catheter either a bolus dose of $100 \mathrm{mg}$ (Group I, $\mathrm{n}=20$ ), or $200 \mathrm{mg}$ (Group II, $\mathrm{n}=$ 20) tramadol or a bolus of $10 \mathrm{ml}$ saline (Control group, $\mathrm{n}=20$ ). Study drug boluses diluted with sodium chloride $0.9 \%$ to $10 \mathrm{ml}$ were prepared by an anesthesiologist who took no part in patient management or assessment. Investigator was unaware of the treatment given. The epidural catheter was removed at the end of surgery. The VAS of pain, as well as side-effects (respiratory depression, vomiting and pruritus) were evaluated at $1,2,4,8,12$ and $24 \mathrm{hr}$ after surgery. Respiratory depression was defined as a respiratory rate $<10 \mathrm{bpm}$. Vomiting and pruritus were rated as absent, mild (present but not requiring treatment) or severe (treatment required). The incidence of urinary retention was not studied, as all patients had an indwelling catheter for at least eight hours after induction of anesthesia.

Pain scores were obtained while the patients were at rest. If the VAS was 2, or upon patient's request, additional analgesics were provided. Patients were initially treated with a suppository of $100 \mathrm{mg}$ diclofenac. If no relief was observed within $30 \mathrm{~min}, 1.0 \mathrm{mg} \cdot \mathrm{kg}^{-1}$ meperidine im was administered. Pain scores, time to first analgesic request, cumulative doses of diclofenac and meperidine, as well as the incidence of adverse events (respiratory depression, vomiting and pruritus) for the first $24 \mathrm{hr}$ after operation were compared in the three groups.

Statistical analysis. All data are presented as mean \pm SD. One-way analysis of variance (ANOVA) was used to test the difference in patient characteristics (age, weight, height), between drug doses, VAS and the mean time to first analgesic administration. The Scheffe' test was used for comparison of measured variables between two groups. $P<0.05$ was considered statistically significant.

TABLE I Demographic Data

\begin{tabular}{llll}
\hline & Control & Group I & Group II \\
\hline Age (yr) & $34 \pm 6$ & $31 \pm 6$ & $31 \pm 4$ \\
Weight $(\mathrm{kg})$ & $\mathbf{8 0 \pm 1 4}$ & $77 \pm 12$ & $84 \pm 12$ \\
Height(cm) & $162 \pm 6$ & $162 \pm 6$ & $163 \pm 3$ \\
\% of first Cesarean section & $30 \%$ & $25 \%$ & $30 \%$ \\
\% of repeat Cesarean section & $70 \%$ & $75 \%$ & $70 \%$ \\
\hline
\end{tabular}

Mean age, weight and height, as well as the percentage of first $v s$ repeat Cesarean secrion in the control group vs the $100 \mathrm{mg}$ tramadol group (Group I) and the $200 \mathrm{mg}$ tramadol group (Group II). 
TABLE II Postoperative mean visual analog pain scores (VAS) during the first $24 \mathrm{hr}$, analgesic requirements of demerol and diclofenac (voltaren), as well as the mean time to the first analgesic administration in the control group $v s$ the $100 \mathrm{mg}$ and $200 \mathrm{mg}$ tramadol groups.

\begin{tabular}{lllll}
\hline & VAS $(\mathrm{cm})$ & $\begin{array}{l}\text { Mean time to first } \\
\text { analgesic }(\mathrm{br})\end{array}$ & Demerol $\left(\mathrm{mg} \cdot \mathrm{kg}^{-1}\right)$ & Voltarene(mg) \\
\hline Control & $2.56 \pm 0.80$ & $2.8 \pm 2.0$ & $0.70 \pm 0.40$ & $214 \pm 70$ \\
Tramadol 100 & $0.91 \pm 0.84^{*}$ & $4.5 \pm 3.1^{*}$ & $0.31 \pm 0.30^{*}$ & $156 \pm 59^{*}$ \\
Tramadol 200 & $1.12 \pm 0.40^{*}$ & $6.6 \pm 3.4^{*}$ & $0.30 \pm 0.33^{*}$ & $142 \pm 62^{\star}$ \\
\hline
\end{tabular}

* $P<0.05$ vs Control

\section{Results}

There were no intergroup differences in age, weight, height, as well as the percentage of first vs repeat Cesarean section (Table I).

The mean VAS values taken at $1,2,4,8,12$ and 24 hr postoperatively was lower in the tramadol groups than in the control group. Also, the mean time to first analgesic administration was longer in the patients who received tramadol than in those who had received the placebo. The mean cumulative doses of meperidine and diclofenac over $24 \mathrm{hr}$ were lower in the patients who received $100 \mathrm{mg}$ of tramadol and those who received $200 \mathrm{mg}$ of tramadol than in the control group (Table II). However, no difference was obtained between patients receiving $100 \mathrm{mg}$ tramadol and $200 \mathrm{mg}$ tramadol concerning all parameters studied. In the three groups, adverse side-effects such as respiratory depression, vomiting and pruritus were not observed.

\section{Discussion}

The use of epidural opioids to relieve postoperative pain following Cesarean delivery has been advocated. In 1979, Wolfe and Nicholas reported that epidural $100 \mu \mathrm{g}$ fentanyl relieved postoperative pain in 20 patients who had undergone elective Cesarean section. ${ }^{14}$ Also, Kotelko and co-workers reviewed their experience using $5 \mathrm{mg}$ epidural morphine for analgesia in 276 healthy women undergoing Cesarean delivery. They found that good to excellent analgesia had been achieved, lasting $24-36 \mathrm{hr}$ for $83 \%$ of the patients. ${ }^{15}$ The most serious side-effect encountered with epidural opioids is delayed respiratory depression. Morphine is most commonly associated with this complication. The relatively low lipid solubility of morphine is thought to account for its tendency for cephalad spread in the CSF. Thus, close observation is recommended for $24 \mathrm{hr}$ after the last injection. ${ }^{16-19}$

Tramadol is a weak agonist at all types of opioid receptors with some selectivity for $\mu$ receptors. ${ }^{20}$ Also, mechanisms of action of non-opioid receptors may contribute to the analgesic profile. Tramadol inhibits nora- drenaline uptake and stimulates serotonin release, and these are transmitters in the descending inhibitory pathways which enhance analgesia. ${ }^{21,22}$ The non-opioid mechanisms may potentiate the analgesia of epidural tramadol, without inducing respiratory depression.

The present report shows that both 100 and 200 mg epidural tramadol provide adequate postoperative pain relief following Cesarèan section, as evidenced by lower VAS, longer mean time to the first analgesia request, and less requirement for supplementary analgesics than in the control group. However, no difference was found between patients receiving $100 \mathrm{mg}$ and $200 \mathrm{mg}$ tramadol, concerning all parameters studied. This ceiling effect of tramadol is similar to that achieved in a previous study showing that epidural morphine $5 \mathrm{mg}$ was as effective as $7.5 \mathrm{mg}$ in providing postoperative analgesia after Cesarean delivery, as evidenced by the same onset time, peak analgesia and duration of analgesia. ${ }^{5}$

Adverse side-effects following epidural opioids include respiratory depression, pruritus, nausea, vomiting and urinary retention: ${ }^{16-19}$ the most serious is early or delayed respiratory depression. Our study did not show any evidence of respiratory depression, even with subsequent administration of additional analgesics. However, delayed respiratory depression is such a rare occurrence, that one may not encounter this complication in a limited number of patients. The most common side-effect of spinal or epidural opioids is pruritus, which is related to the cephalad migration of the narcotic in the CSF. In patients given intrathecal $1.0 \mathrm{mg}$ for morphine labor and delivery pain, Baraka and coworkers found $100 \%$ incidence of pruritus. ${ }^{23}$ None of our patients receiving epidural tramadol complained of pruritus. The most frequently reported side-effect with tramadol is nausea and/or vomiting. This can be explained by the 5-HT action of the drug. It occurs more frequently after intravenous than intramuscular administration of tramadol ${ }^{24}$ Also, it has been reported when epidural tramadol was used following abdominal surgery. ${ }^{13}$ In our study, no patient complained of vomiting which is an added advantage to the use of epidur- 
al tramadol in parturients delivering by Cesarean section. A larger patient population may be needed to show conclusively that epidural tramadol has no adverse side effects. Only $0.1 \%$ of a dose of tramadol was found to be excreted in the milk of lactating women, an amount which is unlikely to produce clinically important effects in infants. ${ }^{24}$

Diclofenac has been reported to improve analgesia provided by small doses of epidural and intrathecal morphine after Cesarean analgesia. ${ }^{25-26}$ In our report, diclofenac, a nonsteroidal anti-inflammatory drug, was also used as a first line drug when administration of additional analgesic medication was needed. There is a theoretical risk of increased bleeding after NSAIDS due to decreased platelet function ${ }^{27}$ and tocolytic activity. ${ }^{28}$ No side effects of this nature were observed.

In conclusion, our report shows that $100 \mathrm{mg}$ or $200 \mathrm{mg}$ epidural tramadol can safely provide adequate postoperative pain relief after Cesarean delivery, compared with epidural saline. This was evidenced by a decrease of the mean of the VAS values taken at 1,2 , $4,8,12$ and $24 \mathrm{hr}$ postoperatively, as well as by the significant increase of the mean time to the first analgesic administration. Also, the mean cumulative doses of meperidine and diclofenac requirements over $24 \mathrm{hr}$ postoperatively were significantly lower in the tramadol groups than the control group. Other side effects such as clinical respiratory depression, vomiting or pruritus were not observed. There was no difference between the $100 \mathrm{mg}$ and $200 \mathrm{mg}$ epidural tramadol groups.

\section{References}

1 Uchiyama A, Ueyama $H$, Nakano S, Nishimura $M$, Tashiro $C$. Low dose intrathecal morphine and pain relief following cesarean section. Int J Obst Anesth 1994; 3: 87-91.

2 Abouleish E, Rawal N, Fallon K, Hernandez D. Combined intrathecal morphine and bupivacaine for cesarean section. Anesth Analg 1988; 67: 370-4.

3 Chadwick HS, Ready LB. Intrathecal and epidural morphine sulfate for postcesarean analgesia - a clinical comparison. Anesthesiology 1988; 68: 925-9.

4 Abboud TK, Dror A, Mosaad $P$, et al. Mini-dose intracheal morphine for the relief of post-cesarean section pain: safety, efficacy and ventilatory responses to carbon dioxide. Anesth Analg 1988; 67: 137-43.

5 Rosen MA, Hughes SC, Shnider SM, et al. Epidural morphine for the relief of postoperative pain after cesarean delivery. Anesth Analg 1983; 62: 666-72.

6 Raffa $R B$, Friderichs E, Reimann W, Shank RP, Codd EE, Vaught JL. Opioid and nonopioid components independently contribute to the mechanism of action of tramadol, an 'atypical' opioid analgesic. J Pharmacol Exp Ther 1992; 260: 275-85.

7 Houmes R-JM, Voets $M A$, Verkaaik A, Erdmann W, Lachmann $B$. Efficacy and safety of tramadol versus morphine for moderate and severe postoperative pain with special regard to respiratory depression. Anesth Analg 1992; 74: 510-4.

8 Vickers $M D$, O'Flaberty $D$, Szekely SM, Read $M$, Yoshizumi J. Tramadol: pain relief by an opioid without depression of respiration. Anaesthesia 1992; 47: 291-6.

9 Eggers KA, Power I. Tramadol (Editorial). Br J Anaesth 1995; 74: 247-9.

10 Sunshine A, Olson NZ, Zigbelboim I, DeCastro A, Minn $F L$. Analgesic oral efficacy of tramadol hydrochloride in postoperative pain. Clin Pharmacol Ther 1992; 51: 740-6.

11 Carlsson $K-H$, Jurna $I$. Effects of tramadol on motor and sensory responses of the spinal nociceptive system in the rat. Eur J Pharmacol 1987; 139: 1-10.

12 Baraka $A$, Jabbour S, Gbabash $M$, Nader A, Khoury G, Sibai $A$. A comparison of epidural tramadol and epidural morphine for postoperative analgesia. Can J Anaesth 1993; 40: 308-13.

13 Delilkan AE, Vijayan R. Epidural tramadol for postoperative pain relief. Anaesthesia 1993; 48: 328-31.

14 Wolfe $M J$, Nicholas $A D G$. Selective epidural analgesia (Letter). Lancet 1979; 2 : 150-1.

15 Kotelko DM, Dailey PA, Shnider SM, Rosen MA, Hughes $S C$, Brizgys RV. Epidural morphine analgesia after Cesarean delivery. Obstet Gynecol 1984; 63: 409-13.

16 Etches $R C$, Sandler $A N$, Daley $M D$. Respiratory depression and spinal opioids. Can J Anaesth 1989; 36 : 165-85.

17 Cousins MJ, Mather LE. Intrathecal and epidural administration of opioids. Anesthesiology 1984; 61: 276-310.

18 Bromage $P R$. The price of intraspinal narcotic analgesia: basic constraints (Editorial). Anesth Analg 1981; 60: 461-3.

19 Rawal N, Wattwil $M$. Respiratory depression after epidural morphine - an experimental and clinical study. Anesth Analg 1984; 63: 8-14.

20 Hennies $H H$, Friderichs $E$, Schneider J. Receptor binding, analgesic and antitussive potency of tramadol and other selected opioids. Azzneimittel-Forshung/Drug Research 1988; 38: 877-80.

21 Dhasmana KM, Banerjee AK, Rating W, Erdmann W. Analgesic effect of tramadol in the rat. Chung Kuo Yao Li Hsueh Pao - Acta Pharmacologica Sinica 1989; 10: 289-93.

22 Kayser V, Besson J-M, Guildbaud G. Effects of the analgesic agent tramadol in normal and arthritic rats; comparison with the effects of different opioids, including 
tolerance and cross-tolerance ot morphine. Eur J Pharmacol 1991; 195: 37-45.

23 Baraka $A$, Noueibid $R$, Hajj $S$. Intrathecal injection of morphine for obstetric analgesia. Anesthesiology 1981, 54: $136-40$.

24 Lee CR, McTavish D, Sorkin EM. Tramadol. A preliminary review of its pharmacodynamic and pharmacokinetic properties, and therapeutic potential in acute and chronic pain states. Drugs $1993 ; 46: 313-40$.

25 Dennis AR, Leeson-Payne CG, Hobbs GJ. Analgesia after Caesarean section. Anaesthesia 1995; 50: 297-9.

26 Cardoso MMSC, Carvalho JCA, Amaro AR, Prado AA, Cappelli $E L$. Small doses of intrathecal morphine combined with systemic diclofenac for postoperative pain control after cesarean delivery. Anesth Analg 1998; 86: 538-41.

27 Power I, Chambers WA, Greer IA, Ramage D, Simon E. Platelet function after intramuscular diclofenac. Anaesthesia 1990; 45: 916-9.

28 Andersson $K-E$, Forman $A$, Ulmsten $U$. Pharmacology of labor. Clin Obstet Gynecol 1983; 26: 56-77. 